\title{
Resource categories and performance in Portuguese non-profit sports clubs
}

\author{
Marco Arraya ${ }^{\dagger}$ \\ Universidade Aberta, Lisboa, Portugal
}

\begin{abstract}
The resource-based view (RBV) explores the role of key resources identified as tangible, personnelbased, and intangible resources in creating superior organizational performance. The RBV posits that an organization's success is mainly driven by resources that possess Barney's VRIO (valuable, rare, inimitable, and organized) framework. The purpose of this study is to demonstrate the relationship between the three categories of resources and organizational performance. The data was analyzed with a two-stage structural equation modelling approach. The sample included Portuguese sports management staff from non-profit clubs which composed of 375 men and 102 women. The results of the structural model demonstrated that, intangible resources can significantly influence organizational performance while, personnel-based resources influence tangible and intangible resources. The results show that "staff competence", "reputation", and "financial capital" were the most essential resources, and that is core for non-profit clubs and their strategy to recognize, develop, and leverage VRIO resources. These findings also have considerable implications for sport managers, and suggestions for possible future research were given.
\end{abstract}

Keywords: Resource-based view(RBV); VRIO, structural equation modelling(SEM); performance, sports clubs.

\footnotetext{
*Author for correspondence:

$\dagger$. Doctorate degree

Universidade Aberta, Lisboa, Portugal

Address: Rua da Escola Politécnica Lisboa,

E-mail: marco.arraya@marcoarraya.com
} 


\section{INTRODUCTION}

$\mathrm{T}$

he difficult financial situation of most non-profit sports clubs, their fighting for financial and human resources, their different challenges such as increasing competition through sponsors, nonexistence of public subsidies, demographic change and the growing sports competition between peers, forces sports managers to understand how to create, develop, buy, accumulate, combine, or utilize their resources or assets in the best way to compete and create value (Sirmon, Hitt, \& Ireland, 2007).

A sport club is defined as a group of individuals organized for the purpose of furthering and promoting their interest in sports or athletic activity. The purpose of the club should be to promote health, physical well-being and the acquisition of physical skill development. A sport club also offers opportunities for development of life skills such as leadership, cooperation, public relations, scheduling, budgeting, organizational dynamics, sportsmanship, and teamwork. The sport club may be recreational, instructional, and/or competitive in nature. Members may display a variety of skill levels and may place varying degrees of emphasis on extramural competition.

A non-profit club has two main features: (1) constitutive features. This means that most of the staff is voluntary, democratic, and autonomous; and (2) economic features that are identity of member roles, non-profit orientation, autonomous revenues, and the principle of solidarity (Horch, 1994). Club members are decision-makers, producers, consumers, and at the same time, financiers of the club's sport supply (Wicker \& Breuer, 2011).

It has been recognized that innovation in sports is fundamental in a rapidly changing global economic environment (Ratten, 2011). Thus, this innovation needs a system with high levels of resourcing in terms of human resources, infrastructure, finance, competence and knowledge in order to create an advantage and consequent high organizational performance (Barreto, 2010).

Therefore, to dibble a culture of innovation and resource effectiveness is a responsibility for everyone. Resource management is a major task of efficiency with positive effects on performance (Barney, 2001). The resource-based view (RBV) approach can provide a basis for understanding the role that resources play in the organizational performance of non-profit sports clubs (Arraya, 2014).

Lechner and Gudmundsson (2012) argued that the RBV approach can be applied to studying the performance of sports teams. Their research concluded that: (1) it is the combination and development of high-quality resources that make a difference; and (2) the analysis of single resources hide important relationships. On the other hand, Brown and Kimbrough (2011) and Mnzava (2013) highlight the importance and success of intangible resources in sports organizations. However, there is a field of investigation about the contribution of tangible and personnel-based resources to performance in sports clubs. 
This research attempts to investigate the contribution of different resources and its categories to achieve superior organizational performance. Drawing from the RBV (Lockett, Thomson, \& Morgenstern 2009) and past literature, this study identifies categories of resources as potential influencers of organizational performance and which resources are considered most important for success in Portuguese non-profit sports clubs.

The study is organized as follows: after the introduction, the second section provides a literature review together with hypotheses. The third section presents the methods. The fourth section deals with data analysis. The fifth section deals with the discussion. The sixth section presents the conclusions and contributions. The last section describes the limitations and potential future research.

\section{LITERATURE REVIEW}

Strategic management research suggests that organizations need to seek a strategic fit between the external environment and internal resources. However, the literature also suggests that the internal resources of an organization rather than the external environment around the organization are possibly the primary source of performance differences among organizations (Das \& Teng, 2000). According to this thought the RBV has a considerable influence within strategic management, due to its focus on organization' idiosyncrasies as determinants of competitive advantage (Poppo \& Weigelt, 2000) and simultaneously it can be a justification of performance differences between organizations, thus, those that best manage its resources can achieve an advantage (Barney \& Arikan, 2001).

The RBV assumes that the strategic resources of organizations within an industry are not homogeneously distributed. It also assumes that these resources are not perfectly mobile and, therefore, that differences between organizations may persist over time (Barney, 2001). This perspective suggests that the market is often constricted by organizations' inability to replicate the strategies of the most successful ones. It is when this happens that organizations are able to earn economic rents, create an advantage, or both; what this suggests for non-profit clubs is that their value as strategic resources will be determined by their ability to contribute to competitive strategies that are difficult to emulate (Mauws, Mason, \& Foster, 2003).

In his study, we follow Daft's (1983) resource definition “all assets, capabilities, organizational processes, firm attributes, information, knowledge, etc. controlled by a firm that enable the firm to conceive of and implement strategies that improve its efficiency and effectiveness" (p. 540).

The RBV argues that when a resource has simultaneously four particular characteristics, it is VRIO (Barney \& Hesterly, 2009): 1) Valuable, i.e., the resource must be capable of allowing an organization to increase value to customers, and also to take advantage of opportunities and minimize threats; 2) Rare; a valuable resource must be held and explored by few players, otherwise, 
any possible advantage generated will be a commodity (Barney \& Zajac, 1994); 3) Inimitability; if a value and rare resource is easily imitable, all players would promptly copy it, thereby losing its advantage; 4) Organization; competitive advantage stems from the way players manage and interconnect their strategic and ordinary resources (Pan, Tan, Huang, \& Poulsen, 2007; Warnier, Weppe, \& Lecocq, 2013) by exploiting organizational processes and routines in search of quality products/services.

Some scholars argue that an organization has two kinds of resources: strategic and ordinary (Barney, 1991; Warnie et al., 2013). According to Warnie et al. (2013), "a strategic resource is a rare resource on the market, generally perceived as positive in terms of performance, i.e. with an expected level of productivity that is greater than its cost (acquisition or development). Such a resource is considered a potential source of rents ... an ordinary resource is a common resource on the market, generally perceived as neutral in terms of performance, i.e. with an expected level of productivity equivalent to its cost (acquisition or development). Such a resource is considered, at best, as ensuring competitive parity” (p. 1362).

The resource heterogeneity gives room for some competitors to own more strategic resources than others, and because strategic resources induce rents, a competitor that owns them can develop or expand advantages (Hoopes, Madsen, \& Walker, 2003). The ordinary resources constitute an organization's assets, and due to their regular use and universal nature, appear as commodity resources in which "productivity is equal to the cost of their acquisition or development" (Warnie et al., 2013; p. 1361). As a strategic line of thought, the RBV helps the organization to analyse their strengths and weaknesses (Curado \& Bontis, 2006).

The configuration of strategic and ordinary resources guarantees the superior organization's performance. This resource configuration is defined as a dynamic open system which evolved from the orchestrated ordinary and strategic resources (Hafeez, Zhang, \& Malak, 2002; Miller, 1996; Warnie et al., 2013), connected with a holistic behaviour. This means, the organization should concentrate its efforts on the bundles of embedded resources that create a source of advantage (Barney \& Griffin, 1992; Black \& Boal, 1994).

Management authors have identified four to six categories of strategic resources that organizations use to plan and execute their strategies. These are: financial, physical, human, and organizational capital (Barney, 2002; Barney \& Arikan, 2001; David, 2011); technological capabilities (Lichtenstein \& Brush, 2001); and social capital resources (Ireland, Webb, \& Coombs, 2005). However, resources can also be broken down into three fundamental categories. Following David (2011), the internal resources can be grouped into physical resources, human resources, and organizational resources; according to Barney and Hesterly (2009), Bharadwaj (2000), Galbreath (2005), Grant (2002) and Simon (2010), internal resources can be grouped into tangible resources, 
personnel-based resources, and intangible resources. Any of these categories have an important role in creating an organization's value (Carmeli \& Tishler, 2004). As can be seen, research and literature to date, have provided a large range of distinct categories; this study segments resources into tangible, intangible and personnel-based.

Tangible resources (TR) include those factors containing financial or physical value as measured by the organization's balance sheet (Andersen \& Kheam, 1998). These includes: product/ process inputs, facilities, locations, patents, and technological equipment. They can be protected from imitation by copyright (Miller \& Shamsie, 1996).

Intangible resources (IR) are implicit and difficult to codify (Conner \& Prahalad, 1996), hard to acquire, to develop, to replicate, accumulate within the organization (Winter, 1987), and are considered as assets [things that a firm owns, i.e., intellectual property such as patents, trademarks, trade secrets or databases; Hall, (1992)]. They also show evidence of complementarities (Rivkin, 2000), and they are people independent (Hall, 1992). Due to all of these, they are difficult to be understood and imitated by competitors (Nelson, 1991) creating a potential superior performance. Furthermore, they allow the organization to add value to their tangible resources (Hall, 1992, Miller \& Shamsie, 1996). Intangible resources include those factors that are non-physical, non-financial in nature (Andersen \& Kheam, 1998), and non personnel-based resources.

Personnel-based resources (PBR) refer to those factors that are attributes of the organization itself; that is, the manpower skills associated with an organization -i.e. competencies, such as the know-how of employees, collective aptitudes, culture or training- (Barney \& Arikan, 2002; Hall, 1992). PBR are the organization's internal systems, structures, and routines. They include internal social capital resources (Ireland, Hitt, \& Sirmon, 2003); organizational culture (Hansen \& Wernerfelt, 1989); planning, controlling, and coordinating systems (Barney, 1991); reporting structures; operating routines (Nelson \& Winter, 1982). All of these factors are people dependent (Hall, 1992). They are ordinary resources and rarely drive organization growth; however, their coordinating mechanisms are decisive for maintaining expansion.

Given the fact that resources are aggregate in categories, and that they are the organization's foundation for organizational performance, we offer the following hypothesis and one question:

- H1: Tangible, intangible, and personnel-based resources have a positive influence on performance.

- H2 - Personnel-based resources have a positive influence on tangible and intangible resources.

- Q1 - What are the resources of sports organization's which are considered most important for success by Portuguese non-profit sports clubs staff? 
The fundamental inference of RBV is that, sports managers should seek to develop and exploit the organization's resources, and according to Aaker (1989), the pathway to advantage consists of (1) identifying the appropriate resources and skills; (2) selecting the resources and skills which will be pertinent in the future, and (3) implementing programs which will develop, enhance, and/or protect these resources and skills.

\section{METHOD}

The cross-sectional survey method within the positivist tradition of scholarly inquiry was used in the current study. The content validity of the instrument was evaluated by a panel of experts; this panel included three tenured university professors with extensive expertise in sports management. The panel of experts was asked to check content relevance, representativeness, and clarity of the items. Revisions and improvements to the instrument were made per panel suggestions.

\subsection{Participants}

Participants in this study were volunteers, employees, administrative staff, coaches, trainers, supervisors, and executive members who work in Portuguese non-profit sports clubs were asked to complete a survey. There are three reasons for collecting a wider set of responses: (1) Organizations are a complex open system (Lewin \& Regine, 1999), where the whole is stronger than the sum of its parts, and therefore, it cannot be assumed that an executive or high-level member may have all knowledge regarding the working conditions all over the organization (Kianto, 2009); (2) Sometimes, executive or high-level members overestimate their organization's strengths, which flaws the collected data (Price, 1997); (3). The t-tests demonstrated that the responses of executive or high-level members are considerably different from the other members in about half of the items. This means that, surveying only this segment does not adequately portray the organization as a whole (Kianto, 2009).

Online respondents were recruited from an internet professional network (LinkedIn). The survey was sent to these individuals, and a total of 17,850 surveys from 31 LinkedIn profiled sports management groups were emailed (July-August 2015). The first question was eliminatory, because it would select potential participants: Do you work as a professional or volunteer in a Portuguese non-profit sports club?

A total of 658 respondents answered the survey (3.69\% response rate) with 477 valid responses (2.67\%). The participants composed of $78.62 \%$ male and $21.38 \%$ female. The average age of the participants is 38.92 ( $\mathrm{SD}=10.05)$, ranging from 19 to 69 years old, of which $88.05 \%$ have a university degree [Bachelor's degree (34.48\%), Master's degree (41.93\%), and $\mathrm{PhD}(11.74 \%)$. 


\subsection{Dimensions}

The independent variables are: (1) tangible resources (TR) were measured using three items; (2) personnel-based resources (PBR) were measured using nine items; (3) intangible resources (IR) were measured using six items.

Performance (PER) is a dependent construct, and it is characterized by the non-profit sports clubs' staff perception, measured using two items (Dobson \& Goddard, 2004; Jaworski \& Kohli, 1993). The scales measured the respondents for their subjective assessment of their organization's overall performance, and face the major competitors over the last three years. All measures were assessed using a five-point Likert-type scale from $1=$ totally unimportant to $5=$ of utmost importance.

\subsection{Statistical instrument}

The purpose of this study was to examine the influence of TR, PBR and IR in organizational performance. Structural Equation Modelling (SEM) was used to test the hypotheses of the work, aided by AMOS 21.0, which is suitable for this sample size. For the purpose of SEM, a sample size of 477 is considered good (Kline, 1998). SEM is a multivariate statistical technique used to examine and confirm the relationships of latent variables in a model strongly guided by theory (Carpenter, 2008). Using the Anderson and Gerbing's (1988) two-step approach will guarantee a comprehensive, confirmatory assessment of construct validity (Hu \& Bentler, 1999). In stage 1, this study developed and confirmed an effective measurement model using Confirmatory Factor Analysis (CFA) whose objective is to ensure we are measuring what we believe we are measuring [convergent validity and discriminant validity (Campbell \& Fiske, 1959)]. Given acceptable convergent and discriminant validities, in stage 2, after the measurement model was tested to guarantee fitting construct measurement, the structural model will impute the relationships among latent and dependent constructs which constitutes a confirmatory assessment of nomological validity (Cronbach \& Meehl, 1955). The use of SEM seemed justified, given that the purpose of

this study is to examine the relations between the three resources' categories defined by theory and performance.

Respondents were also requested to rank the top five resources using the three resources' constructs of the research. A weighted score was calculated for each of the items in order to obtain a clear ranking. The formula used to calculate (Simon, 2010) designed the weighted score.

\section{Data Analysis}

The current study follows Anderson and Gerbing's (1988) two-stage modelling approach. The maximum likelihood (ML) method of covariance structure analysis was used, and as well a 
set of fit indexes reflecting the recommendations about what to report in written summaries of the CFA (Boomsma, 2000; McDonald and Ho, 2002) which includes: (1) model chi-square $\chi^{2}[\geq 0,05$, Tabachnick \& Fidell, (2007)]; (2) Goodness of Fit Index (GFI) (Joreskog \& Sorbom, 1984); (3) Comparative Fit Index (CIF) (Hu \& Bentler, 1998); (4) Non-Normed Fit Index (NNFI) (Bentler \& Bonett, 1980); GFI/CFI/NNFI $\geq 0,90$ (Hu \& Bentler, 1998); (5) the Steiger-Lind root mean square error of approximation [(RMSEA; Steiger, 1990; $\leq 0,08$ (Browne \& Cudeck, 1993)]. Cronbach's coefficient alpha (Churchill, 1979; Cortina, 1993) and construct reliability coefficient (Fornell \& Larcker, 1981; Hair, Black, Babin, \& Anderson, 2010) were used to examine the consistency of responses across the items within a single measure.

\subsection{Common method bias and measurement validity}

This study uses two preventative design and statistical procedures to minimize common method bias: (1) it follows Harrison, McLaughlin, and Coalter (1996) because it is using multiple item constructs instead of item level; (2) according to Podsakoff and Organ (1986), the Harman's single-factor test is a good tool to check for this potential problem. The Harman single-factor test requires loading all multiple-item constructs, thereby resulting in an exploratory factor analysis in this case and according to the expected factor solution that accounts for $61.13 \%$ of the total variance, and also the first factor, which by itself accounts for $29.99 \%$; because of a single factor, solution does not emerge, and the first factor does not explain most of the variance, therefore, common method bias is not a serious concern for this study (Zou \& Chen, 2008; p. 14).

There is a strong relationship between reliability and validity, because, a test can be reliable, but not valid. A test cannot be valid without first being reliable (Salkind, 2012). In other words, high accuracy is not synonymous with the construct being measured properly. For this reason, after the reliability analysis is determined, be sure to validate the entire model extent. Reliability and validity issues were addressed in this study using several methods, such as CFA, reliability analysis, convergent and discriminant validity.

In order to assess reliability, two items were dropped from further analysis. After deleting, all constructs showed acceptable levels of reliability, as evidenced by the internal consistency coefficients (Cronbach Alpha; Churchill, 1979; Cortina, 1993) ranging from 0.69 (TR) to 0.84 (PBR) (Table 1).

Convergent validity was determined from the measurement model by examining whether each indicator estimated, loaded on its posited underlying factor was large. The evaluation was done by using critical values of $Z$ distribution. Since we used AMOS software Critical Ratio (CR), their level of significance and the weight of the items on their respective constructs (Bagozzi \& Yi, 2012) was used. In practical terms, it is evidenced by standardized weight factorial (loadings, completely 
Table 1. Means, standard deviations, item-to-total (I-T-T), factor loadings ( $\chi$ ), estimate $(\beta)$, internal consistency $(\alpha)$, variance explained (VE), critical ratio $(\mathrm{CR})$ and Kaiser-Meyer-Olkin (KMO) for TR, PBR, IR, CS and PER scales.

\begin{tabular}{|c|c|c|c|c|c|c|c|c|c|c|}
\hline & Items & M & SD & I-T-T & $\chi$ & $\beta$ & $\alpha$ & VE & $\mathrm{CR}$ & $\mathrm{KMO}$ \\
\hline TR & & & & & & & 0.69 & $52.61 \%$ & 0.679 & 0,68 \\
\hline TR1 & Geographic location & 3.46 & 1.13 & 0.25 & 0.57 & 0.602 & & & & \\
\hline TR2 & Financial capital & 4.05 & 0.86 & 0.33 & 0.74 & 0.662 & & & & \\
\hline TR3 & Physical assets of the firm & 3.36 & 1.04 & 0.47 & 0.84 & 1.000 & & & & \\
\hline PBR & & & & & & & 0.84 & $48.72 \%$ & 0.848 & 0.86 \\
\hline PBR1 & Employee loyalty & 4.14 & 0.88 & 0.54 & 0.66 & 0.946 & & & & \\
\hline PBR2 & Staff experience & 3.95 & 0.86 & 0.60 & 0.72 & 0.892 & & & & \\
\hline PBR3 & Staff competence & 4.44 & 0.72 & 0.65 & 0.76 & 0.861 & & & & \\
\hline PBR4 & Employees training & 3.95 & 0.95 & 0.57 & 0.69 & 0.149 & & & & \\
\hline PBR5 & $\begin{array}{l}\text { Relationships between staff eg., } \\
\text { teamwork }\end{array}$ & 4.32 & 0.76 & 0.76 & 0.77 & 1.000 & & & & \\
\hline PBR6 & Technological know-how & 3.78 & 0.83 & 0.59 & 0.70 & 0.945 & & & & \\
\hline PBR7 & Other knowledge assets & 3.77 & 0.79 & 0.52 & 0.63 & 0.808 & & & & \\
\hline PBR8 & Top management team & 4.23 & 0.85 & 0.53 & 0.64 & 0.892 & & & & \\
\hline IR & & & & & & & 0.78 & $48.07 \%$ & 0.770 & 0.79 \\
\hline IR1 & Access to good labours & 4.17 & 0.90 & 0.54 & 0.70 & 1.000 & & & & \\
\hline IR2 & Reputation & 4.4 & 0.78 & 0.37 & 052 & 1.029 & & & & \\
\hline IR3 & Brand image & 4.32 & 0.73 & 0.59 & 0.76 & 0.879 & & & & \\
\hline IR4 & Organisational processes & 4.01 & 0.87 & 0.55 & 0.73 & 1.309 & & & & \\
\hline IR5 & Product quality & 4.24 & 0.88 & 0.47 & 0.64 & 1.326 & & & & \\
\hline IR6 & Innovation & 4.19 & 0.87 & 0.63 & 0.78 & 1.290 & & & & \\
\hline PER & & & & & & & 0.74 & $79.17 \%$ & 0.739 & \\
\hline PER1 & $\begin{array}{l}\text { Overall performance of your } \\
\text { organisation on the last three years }\end{array}$ & 3.51 & 0.89 & 0.583 & 0.89 & 1.000 & & & & \\
\hline PER2 & $\begin{array}{l}\text { Overall performance of your } \\
\text { organisation relative to major } \\
\text { competitors on the last three years. }\end{array}$ & 3.62 & 1 & 0.583 & 0.89 & 0.997 & & & & \\
\hline
\end{tabular}

standardized solution) for each indicator with the respective latent variable, and the $t$-value and significance level associated with these loading [ $t$-values $>1.65>1.96$ or $>2.58$ depending $p<0.1$, $p<0.05$ or $p<0.01$, respectively; (Bagozzi \& Yi, 2012)] values are identical to CR. The CFA indicates that, factor loadings of all manifesting observed items are adequate, ranging from 0.56 to 0.89 (>0.50; Hair et al., 2010), and were also significant $(p<0.001)$. This indicates that all the constructs are conforming to the construct convergent validity test.

Discriminant validity finding is essential for conducting latent variable analysis (Fornell \& Larcker, 1981), because, it validates if the hypothesized structural paths results are real, or if they are a result of statistical discrepancies. In testing for the discriminant validity of the latent 
constructs, we followed Zou \& Chen (2008), and the constrained model is considerably poorer than the unconstrained model, in support of discriminant validity (Anderson \& Gerbing, 1988; Bentler, 1978). The results of the measurement model suggest that, the constructs used in this study possessed a satisfactory level of construct validity.

The nomological validity of the model is examined by measuring the goodness of adjustment (Goodness of Fit, GOF) of the model, and also, if the correlations between constructs make sense according to the stipulated theory (Hair et al., 2010). Since the connections between constructs are consistent with the theoretical and empirical research supported by existing literature, the nomological validity will be evaluated by testing the proposed hypotheses from the theories studied. Therefore, the test model constitutes a structural assessment of nomological confirmatory validity (Bentler, 2006). The GOF indexes point out how the model reflects the data, i.e., as the specified model reproduces the covariance matrix among the indicators (Hair et al., 2010), and is the guarantor of rigorous empirical evaluation (Kline, 2005). The measurement model using the maximum likelihood (ML) estimation technique, demonstrated an acceptable fit with the data: $\chi^{2}=548,555 ; \mathrm{df}=193, p<0,001 ; \mathrm{GFI}=0,906 ; \mathrm{CFI}=0,902 ; \mathrm{NNFI}=0,903 ; \mathrm{RMSEA}=0,061$. Thus, it can be deduced that nomological validity is substantiated for all measures used in this study.

Upon specifying appropriate measurement models, the hypothesized structural model was tested. Results from fitting the structural model to the data using ML technique demonstrated an acceptable fit with the data by $\chi^{2}=586.99$; $\mathrm{df}=198, p<0.001$; GFI $=0.904$; CFI $=0.901$; $\mathrm{NNFI}=0.899 ; \mathrm{RMSEA}=0.062$. Overall, the empirical results supported the conceptual model.

\subsection{Hypotheses revisited and correlations}

The relationship between latent factors in the structural model as shown in Table 2 and 3 was used to test hypotheses 1 and 2. Hypothesis 1 was partially supported. "Tangible resources" does not influence "performance"; "personnel based resources" does not influence "performance"; and, "intangible resources" influence "performance". Hypothesis 2 was supported. The "personnel based resources" dimension influences "tangible" and "intangible" dimensions.

The latent construct TR was correlated positively with PBR $(r=0.528)$, IR $(r=0.607)$, CS $(r=0.151)$, and PER $(r=0.168)$. The latent construct PBR was correlated positively with IR $(\mathrm{r}=0.950), \mathrm{CS}(\mathrm{r}=0.289)$, and PER $(\mathrm{r}=0.234)$. The latent construct IR was correlated positively with CS $(r=0.271)$ and PER $(r=0.197)$. The latent construct CS was correlated positively with PER $(\mathrm{r}=0.223)$. All the resources from these three categories correlated positively from "geographic location"/"staff competence" $(\mathrm{r}=0.079)$ to "reputation"/“brand image" (0.591). Overall, all the latent constructs were supported by the correlations (Table 4 and 5). 
Table 2. Sports staff's views on the resources necessary for success

\begin{tabular}{lccc}
\hline Resource & Dimension & Mean (Highest = 5) & Rank score \\
\hline Staff competence & PBR & 4.44 & 427 \\
Reputation & IR & 4.40 & 313 \\
Financial capital & TR & 4.05 & 302 \\
\hline
\end{tabular}

Table 3. State of confirmation of the hypotheses (ML)

\begin{tabular}{lccccc}
\hline Hypotheses & Relationship & Estimate (unstandardized) & S.E. & $p$-value & Result \\
\hline \multirow{3}{*}{ H1 } & TR $\rightarrow$ PER & 0.059 & 0.078 & 0.758 & Not supported \\
& PBR $\rightarrow$ PER & 0.045 & 0.065 & 0.675 & Not supported \\
& IR $\rightarrow$ PER & 0.236 & 0.123 & $1.980^{*}$ & Supported \\
H2 & PBR $\rightarrow$ TR & 0.743 & 0.087 & $8.554^{* * *}$ & Supported \\
& PBR $\rightarrow$ IR & 0.746 & 0.076 & $9.860^{* * *}$ & Supported \\
\hline
\end{tabular}

${ }^{*} p<.05 ; * * p<.01 ; * * * p .001$

Table 4. Standout correlations of Portuguese non-profit sports clubs staff's views on the resources necessary for success

\begin{tabular}{|c|c|c|c|c|c|c|c|c|c|c|c|c|c|}
\hline Resource & $\begin{array}{l}\text { Rank } \\
\text { score }\end{array}$ & Mean & PBR3 & IR2 & TR2 & IR3 & IR5 & IR6 & PBR5 & PBR1 & IR4 & PBR2 & PBR4 \\
\hline PBR3 & 427 & 4.44 & 1 & & & & & & & & & & \\
\hline IR2 & 313 & 4.40 & $.372 * *$ & 1 & & & & & & & & & \\
\hline TR2 & 302 & 4.05 & $.173 * *$ & $.290 * *$ & 1 & & & & & & & & \\
\hline IR3 & 237 & 4.32 & $.302 * *$ & $.591 * *$ & $.213^{* *}$ & 1 & & & & & & & \\
\hline IR5 & 213 & 4.24 & $.414 * *$ & $.463 * *$ & $.221 * *$ & $.408^{* *}$ & 1 & & & & & & \\
\hline IR6 & 165 & 4.19 & & & & & $.544 * *$ & 1 & & & & & \\
\hline PBR5 & 164 & 4.32 & $.585 * *$ & & & & & & 1 & & & & \\
\hline PBR1 & 130 & 4.14 & & & & & & & $.532 * *$ & 1 & & & \\
\hline IR4 & 123 & 4.01 & & & & & & & & & 1 & & \\
\hline PBR2 & 96 & 3.95 & $.557 * *$ & & & & & & & & & 1 & \\
\hline PBR4 & 74 & 3.95 & & & & & & & $.544 * *$ & & $.546^{* *}$ & & 1 \\
\hline
\end{tabular}

** Correlation is significant at the 0.01 level (2-tailed)

Table 5. Correlations among latent constructs and Performance

\begin{tabular}{lcccc}
\hline & TR & PBR & IR & PER \\
\hline TR & 1 & & & \\
PBR & 0.528 & 1 & & \\
IR & 0.607 & 0.950 & 1 & 1 \\
PER & 0.168 & 0.234 & 0.197 & 1 \\
\hline
\end{tabular}

\section{DISCUSSION}

Following the theoretical approach of RBV, this work investigated the influence of TR, IR and PBR on Portuguese non-profit sports clubs. The estimation of the SEM allowed understanding the general causal relationships between the constructs and performance. 
Giving regards to the TR latent construct in this study has a residual influence in sports organizations performance. The reason for this could be the small number of items evaluated (only three). The organization should own money or "financial capital" for investment in core activities that produces outcomes. "Financial capital" is what allows the operational activities to get going, in the search for the returns that will flow from it. A convenient "Geographic location" for sports facilities, particularly those close to transport networks will attract more people. Studies from Berman, Down, and Hill (2002) and Smart and Wolfe (2000) demonstrated that tangible assets (plant, property, and equipment) have influence on sports clubs and their success.

Tangible resources are important in the sports clubs, because, without infrastructures and money, it will be difficult to operate. Nevertheless, personnel based resources are a critical source of organizational success (Khasawneh, 2010). Thus, it is vital that these resources are leveraged properly to provide optimal value for the organisation, because the contribution of PBR is likely to meet or exceed the value of "financial capital".

Relatively to PBR, the significant items are "employee loyalty", "technological know-how", "staff experience", and "top management team". The importance of "top management team" has been recognised by Holcomb, Holmes and Connelly (2009) when they argued that managerial ability is a significant component of value creation, and that managers expertise as regards how to use resources could be as important as owning them. Consequently, these results show the importance of personnel attitude, skills, and knowledge, for good performance.

Some authors (Soh, 2006; Hall, 1993) have argued that intangible resources are the most important category because, they are inimitable, most especially those directly related to an organization as a whole (Hitt, Ireland, Camp, \& Sexton, 2001; Wu, 2006).

The IR latent dimension, even with a lower level of significance has influence on sports organizations performance. The item "product quality" has the standout loading. Organizations are interested in product/service quality due to its potential to create unique brand image and reputation (Porter, 1985), to sell more with attractive margins (Porter, 1985), to expand market share (Buzzell \& Wiersema, 1981), to lower costs of production/operations (Phillips, Chang, \& Buzzell, 1983), and also, to improve productivity, and ultimately increase profits (Forker, Vickery, \& Droge, 1996). According to (Prajogo \& McDermott, 2011), quality jumps from a position of distinctive competence to being a critical success factor or just an ordinary resource; Garvin (1984) suggests that organizations do not need to perform all quality variables in order to be successful. However, quality remains the foundation of superior performance because, only a product/service which fills customer expectation is marketable, maintains existing customers, and attracts new ones, which leads to better performance (Anderson, Fornell, \& Rust, 1997). 
The items "organizational processes" and "innovation" have also had strong contributions as regards this dimension. These two factors will guarantee that the sports organization is working as a whole, improving efficiency, and achieving a better performance without compromising the future. However, "reputation" and "brand image", as the organization's show window, deserves a special attention. A favourable organizational "reputation" and "brand image" are strategic intangible resources that creates superior performance (Roberts \& Dowling, 2002), market value (Black, Jang, \& Kim, 2000), and charging a price premium (Rindova, Williamson, Petkova, \& Sever, 2005) when competitors are not able to match the prestige and esteem they create; also, they help an organization to differentiate itself from others, which is rare, difficult to imitate, and inimitable by others (Barney, 1991).

A favourable reputation offers two distinct factors over competitors: (1) when an organization has a favourable reputation, which is perceived as a stronger performance-trigger by stakeholders, holds a high competitive advantage (Robets \& Dowling, 2002); (2) if reputation persist over time, the competitive advantage will persist also (Love \& Kraatz, 2005). Empirical studies have confirmed that a positive brand image is a strategic resource because, it creates a competitive advantage, allows gaining a better position in the market, increases market share and performance (Park, Jaworski, \& MacInnis, 1986), influences purchase behaviour (Hsieh, Pan, \& Setiono, 2004, Keller, 2008), influences satisfaction (Bloemer \& Ruyter, 1998), which will in turn lead to loyalty [and a loyal customer is the best advertiser for an organization because of the word of mouth (Koo, 2003; Kandampully \& Suhartanto, 2000; Schultz, 2005)] and brand equity (Faircloth, Capella, \& Alford, 2001). Overall, a positive image can have strategic value as it can enhance the organization's competitiveness, generate growth, profitability (Banerjee, 2008; Belén del Río, Vázquez, \& Iglesias, 2001; Juntunen, Saraniemi, Halttu, \& Tähtinen, 2010), and measure the health of the organization (Bennett \& Rundle-Thiele, 2005).

The results concerning question 1 show interesting choices and correlations. The PBR "staff competence" is the standout required resource, and can be defined by the skills and abilities a person has developed, and the level of success of a person's performance (Schultheiss \& Brunstein, 2005). However, respondents have also noted the importance of "reputation", "financial capital", "brand image", and "product quality" resources that interrelate well. The correlations between "staff competence" and "reputation", "staff competence" and "financial capital", and "reputation" and "financial capital" were significant. Since a strategic advantage is associated with a favourable reputation (Davies \& Miles, 1998), which is built on the "staff's competence" shoulders, and because organization's must generate cash flows always (Allen, Bedford, \& Becht, 2011), the link between these three factors makes all sense. According to Murthy (2011), "staff's competence" as a dimension of human capital is antecedent to organizational capital, which then translates 
into financial capital. However, the strongest correlation is "reputation" and "brand image"; these factors together also create VRIO connection.

The first standout facet of the correlational analysis outside the five major is that "relationship between staff" and "staff competence", "relationship between staff" and "employee training", "relationship between staff" and "employee loyalty" have a common indicator, which is, to improve teamwork performance. Secondly, "staff competence" and "staff experience", "employees training" and "organizational processes" also have a common indicator: to improve efficiency.

This is unsurprising, because, what characterized teamwork with a high degree of consistency was positive communication (competence, training and loyalty), high levels of collaboration (competence and training), participation (competence and loyalty) and coordination (competence and training), and low levels of conflict (loyalty) (Shortell, Marsteller, Lin, Pearson, Wu, Mendel, Cretin, \& Rosen, 2004; Temkin-Greener, Gross, Kunitz, \& Mukamel, 2004). In other words, efficiency occurs when team members master skills (competence and experience), combine (training) among themselves, and work on team effectiveness (processes) to build organizational performance (LeMieux-Charles \& McGuire, 2006).

Moving on to the structural model, the coefficients estimated for direct relationships show significant coefficients with an expected positive sign (except TR $\square$ PER). In particular, a hypothesis $\mathrm{H} 2$ is confirmed, whereas, hypothesis $\mathrm{H} 1$ is partially confirmed due to TR to PER not existing, and IR having an even lower level. These results prove the importance of PBR and IR in sports organizations, and it further prevents us from forgetting their contribution for today and tomorrow's rents when used in an effective way (Grajkowska, 2011). Therefore, it is an obligation to own ordinary resources that are required to carry out operations, and as well own strategic resources that are critical for competitive advantages and superior performance (Warnie et al., 2013). Thus, it is core for sports organizations to recognize, develop, and leverage VRIO resources.

\section{CONCLUSION}

Nowadays, sports club managers are aware of how difficult it is to cope with an increasingly uncertain environment, competitors, stakeholders, new business rules, customers; and to manage all these variables, they must now compete on strategic resources in order to outperform their rivals (Prahalad \& Hamel, 1990).

This study focuses on three resource categories and their direct and interactive influence on organizational performance. Using SEM, the study reinforces the argument that PBR and IR are sources to achieve superior performance in the non-profit sports clubs. Thus, the argument that IR, which provide organizations with a frame over competitors in the form of performance, could draw from a VRIO and heterogeneous ability, which enables sports organizations' intangible resources as the ones with more effective influence. 
These empirical results strengthen the argument of the value of IR and PBR to create superior performance through enabling resources, and giving sports managers a validated framework to assess this value. Although, the present study adds contributions to the subjects involved at macro level, further research will be focused on specific resource configurations, relations between resources, as well as investigating other kinds of resources.

In conclusion, this study adopts the argument that: firstly, the RBV is a valuable paradigm for superior performance in the Portuguese non-profit sports clubs. In so doing, the study contributes to the use of RBV in sports clubs. Secondly, this study does more than observe the relationship of one resource category on the performance of the organization; it also observes the simultaneous influence of TR and IR on organizational performance and PBR effect in TR and IR. Thus, it is important that the organization complexity outperforms the market, based on a bundle of resources. Thirdly, this study confirms that, a non-profit club that wants to achieve a superior performance cannot rely on a single category, because, there is also the degree of interaction between them, which creates such a complexity that is difficult to imitate by the competitors, and creates the organization's value. Fourthly, the sports clubs' managers must have the knowledge and caution to provide a relatively accurate combination between strategic and ordinary resources in the search of the overall value of the organization. Lastly, this study indicates the influence of some resources for a non-profit club to innovate, to sustain its advantage and continuous strategy improving. However, different clubs will have different expectations about the resources using and simultaneously different perceptions toward resources produce the possibility of an advantage. This indicates that the abilities of the club or sport manager lie in discovering how to generate the real economic or sport value with its resources in ways that others cannot anticipate.

\section{LIMITATIONS AND POTENTIAL FUTURE RESEARCH}

Even though the research brings significant information about RBV in the Portuguese nonprofit sports clubs, this study has several limitations, and consequently leaves some areas in need of further research. Firstly, this study is limited to one context: Portuguese non-profit sports clubs. Secondly, this study adopted a cross-sectional survey; however, relationships and correlations develop over time. Thus, survey/data should be longitudinal in nature. Thirdly, absolute care should be taken when interpreting the constructs used in this study: (a) the definition used in this work for PBR and IR has only one boundary: human dependent or independent; (b) these two categories are broad dimensions, especially IR, and both have been considered to have only a few variables which create one plausible doubt: what should happen with other variables?; (c) to measure resources and their influence on organisational performance is difficult because of the complexity within them; (d) causality is better tested with a longitudinal survey. Fourthly, RBV's paradigm with its different 
categories of resources, does not fit all industries as an umbrella. Their relative contribution may be different for each industry, which means that, it is not possible to generalize.

Future directions for research might include (1) investigation of the set of strategic and ordinary resources and their influence in sports organizational performance; (2) whether developed internally or acquired on the factor market and (3) how to utilize the VRIO framework and the dynamic capabilities vision for a sustainable competitive advantage. It is also our expectation that this research stimulates further discussion about applying mainstream management concepts to sport. Such discussions should consider not only the resource based view aspects for superior organizational performance, but also the dynamic capability vision. Apart from the above considerations, researchers are invited to contribute with further investigations.

\section{REFERENCES}

Aaker, D. A. (1989). Managing Assets and Skills: The Key to a Sustainable Competitive Advantage. California Management Review, 31(2), 91-106.

Allen, R., Bedford, N., \& Becht, M. A. (2011). A "human ecology economics" framework for Eastern Europe. International Journal of Social Economics, 38(3), 192-208.

Andersen, O., \& Kheam, L. S. (1998). Resource-Based Theory and International Growth Strategies: An Exploratory Study. International Business Review, 7(2), 163-84.

Anderson, E. W., Fornell, C., \& Rust R. T. (1997). Customer satisfaction, productivity, and profitability: differences between goods and services. Marketing Science, 16(2), 129-145.

Anderson, J., \& Gerbing, W. (1988). Structural equation modelling in practice: A review and recommended two stage approach. Psychological Bulletin, 27(1), 5-24.

Arraya, M. (2014). O efeito da alostasia nas organizações e no desempenho: o caso das organizações desportivas. Revista Intercontinental Gestão Desportiva, Rio de Janeiro, 4 (1): 13-70.

Bagozzi, R. P., \& Yi, Y. (2012). Specification, evaluation, and interpretation of structural equation models. Journal of the Academy of Marketing Science, 40, 8-34.

Banerjee, S. (2008). Logo change: Little image touch up or serious overhaul! Imperatives and scanning parameters. Journal of Marketing and Communication, 4(1), 59-70.

Barney J. B., \& Arikan A. (2001). Resource-based view: origins and implications. In The Blackwell Handbook of Strategic Management, Hitt M, Freeman R, Harrison J (eds). Blackwell: Malden, MA.

Barney, J. ., \& Zajac, E. J. (1994). Competitive organizational behavior: Toward an organizationallybased theory of competitive advantage. Strategic Management Journal, 15(S1), 5-9.

Barney, J. B. (1995). Looking Inside for Competitive Advantage. Academy of Management Executive, 9(4), 49-61.

Barney, J. B. (2001). Is the resource-based "view" a useful perspective for strategic management research? Yes. Academy of Management Review, 26, 41-56.

Barney, J. B., \& Griffin, R. W. (1992). The management of organizations: Strategy, structure, behavior. Boston: Houghton Mifflin. 
Barney, J. B., \& Hesterly, W. S. (2009). Strategic management and competitive advantage: concepts and cases. Prentice Hall $3^{\text {rd }}$ edition.

Barreto, I. (2010). Dynamic Capabilities: A Review of Past Research and an Agenda for the Future. Journal of Management, 36(1), 256-280.

Belén del Río, A., Vázquez, R., \& Iglesias, V. (2001). The effects of brand associations on consumer response. Journal of Consumer Marketing, 18(5), 410-425.

Bennet, R., \& Rundle-Thiele, S. (2004). Customer satisfaction should not be the only goal. Journal of Service Marketing, 18(7), 514-523.

Bentler, P.M. (1978). The interdependence of theory, methodology, and empirical data: Causal modeling as an approach to construct validation. In D. B. Kandel (Ed.), Longitudinal drug research (pp. 267-302). New York: Wiley.

Bentler, P.M., \& Bonett, D.G. (1980). Significance tests and the analysis of goodness of fit in the analysis of covariance structures. Psychological Bulletin, 88, 588-606.

Berman, S. L., Down, J., \& Hill, C. W. L. (2002). Tacit knowledge as a source of competitive advantage in the National Basketball Association. Academy of Management Journal, 45(1), 13-32.

Berman, S., Down, J., \& Hill, C. (2002). Tacit knowledge as a source of competitive advantage in the national basketball association. Academy of Management Journal, 45, 13-31.

Bharadwaj, A. S. (2000). A Resource Based Perspective on Information Technology Capability and Firm Performance: An Empirical Investigation. MIS Quarterly, 24(1), 169-196.

Black, B. S., Jang, H., \& Kim, W. (2006). Does Corporate Governance Predict Firms Market Values? Evidence from Korea. The Journal of Law, Economics, and Organization, 22(2), 366-413.

Black, J. A., \& Boal, K. B. (1994). Strategic resources: Traits, configurations and paths to sustainable competitive advantage. Strategic Management Journal, 15, 131-148.

Bloemer, J., \& De Ruyter, K. (1998). On the relationship between store image, store satisfaction and store loyalty. European Journal of Marketing, 32 (5/6), 499-513.

Boomsma, A. (2000). Reporting analyses of covariance structures. Structural Equation Modeling, 7, 461-483. Lawrence Erlbaum Associates, Inc.

Brown, N.C. and Kimbrough, M.D. (2011), "Intangible investment and the importance of firm specific factors in the determination of earnings", Review of Accounting Studies, Vol. 16 No. 3, pp. 539-573.

Browne, M. W., \& Cudeck, R. (1993). Alternative ways of assessing model fit. In K. A. Bollen, J., \& S. Long (1993). Testing structural equation models: 136-162. Newbury Park, CA: Sage.

Buzzell, R. D., \& Wiersema, F. D. (1981). Successful share-building strategies. Harvard Business Review, January-February, 135-44.

Campbell, D. T., \& Fiske, D. W. (1959). Convergent and discriminant validation by the multitraitmultimethod matrix. Psychological Bulletin, 56, 81-105.

Carmeli, A., \& Tishler, A. (2004). The relationships between intangible organizational elements and organizational performance. Strategic Management Journal, 25(13), 1257-1278.

Carpenter, D. M. (2008). Expectations, aspirations, and achievement among Latino students of immigrant families. Marriage and Family Review, 43, 164-185. 
Churchill, G. A. Jr. (1979). A paradigm for developing better measures of marketing constructs. Journal of Marketing Research, XVI, 64-73.

Conner, K. R., \& Prahalad, C.K. (1996). A resource-based theory of the firm: Knowledge versus opportunism. Organization Science, 7, 477-501.

Cortina, J. M. (1993). What is coefficient alpha? An examination of theory and applications. Journal of Applied Psychology, 78, 98-104.

Cronbach, L. J., \& MEEHL, P. E. (1955). Construct validity in psychological tests. Psychological Bulletin, 52, 281-302.

Curado, C., \& Bontis, N. (2006). The knowledge-based view of the firm and its theoretical precursor. Int. J. Learning and Intellectual Capital, 3(4), 367-381.

Daft, R. L. (1983). Learning the craft of organizational research. Academy of Management Reivew, $8,539-546$.

David, F. R. (2011). Strategic management: concepts and cases (13 ${ }^{\text {th }}$ edition). Pearson Education, Upper Saddle River, New Jersey.

Davies, G., \& Miles, L. (1998). Reputation Management: Theory versus Practice. Corporate Reputation Review, 2(1), 16-28.

Das, T. K., \& Teng B-S. (2000). A Resource-based theory of strategic alliances. Journal of Management, 26 (1), 31-61.

Dobson, S. and Goddard, J. (2004), "Revenue divergence and competitive balance in a divisional sports league", Scottish Journal of Political Economy, Vol. 51 No. 3, pp. 359-376.

Faircloth, J. B., Capella, L. M., \& Alford, B. . (2001). The effect of brand attitude and brand image on brand equity. Journal of Marketing Theory and Practice, 9(3), 61-74.

Forker, L. B., Vickery, S.K. \& Droge, C.L. (1996). The contribution of quality to business performance. International Journal of Operations and Production , 16(8), 44-62.

Fornell, C., \& Larcker, D. F. (1981). Evaluating structural equation models with unobservable variables and measurement error. Journal of Marketing Research, 18(1), 39-50.

Galbreath, J. (2005). Which resources matter the most to firm success? An exploratory study of resource-based theory. Technovation, 25, 979-987.

Garvin, D.A. (1984). What does ‘product quality’ really mean? Sloan Management Review, Fall, 25-43.

Grajkowska, A. (2011). Valuing intellectual capital of innovative start-ups. Journal of Intellectual Capital, 12(2), 179-201.

Grant, R.M. (2002). Contemporary Strategy Analysis, 4 edn, Blackwell Publishers Inc, Oxford.

Hafeez, K., Zhang, Y., \& Malak, N. (2002). Determining key capabilities of a firm using analytic hierarchy process. International Journal of Production Economics, 76, 39-51.

Hair, J., Black, W., Babin, B., \& Anderson, R. (2010). Multivariate data analysis ( $7^{\text {th }}$ ed.): PrenticeHall, Inc. Upper Saddle River, NJ, USA.

Hall, R. (1992). Strategic Analysis of Intangible Resources. Strategic Management Journal, 135-144.

Hansen, G. S., \& Wernerfelt, B. (1989). Determinants of Firm Performance: The Relative Importance of Economic and Organizational Factors. Strategic Management Journal, 10(5), 399-411. 
Harrison, D. A., McLaughlin, M. E., \& Coalter, T. M. (1996). Context, Cognition, and Common Method Variance: Psychometric and Verbal Protocol Evidence. Organizational Behavior and Human Decision Processes, 68 (3), 246-61.

Hitt, M., Ireland, R. D., Camp, S. M., \& Sexton, D. L. (2001). Guest Editors' Introduction to The Special Issue, Strategic Entrepreneurship: Entrepreneurial Strategies for Wealth Creation. Strategic Management Journal, 22, 479-491.

Hoopes D. G., Madsen T. L., \& Walker, G. (2003). Guest editors' introduction to the special issue: Why is there a resource-based view? Toward a theory of competitive heterogeneity. Strategic Management Journal, Special Issue 24(10), 889 - 902.

Horch, H.D. (1994). On the socio-economics of voluntary associations. Voluntas, 5(2), 219-230.

Hsieh, M. H., Pan, S. L., \& Setiono, R. (2004). Product, corporate, and country-image dimensions and purchase behavior: A multicountry analysis. Journal of the Academy of Marketing Science, 32(3), 251-270.

Hu, L. T., \& Bentler, P. M. (1998). Fit indices in covariance structure modeling: Sensitivity to underparameterized model misspecification. Psychological Methods, 3, 424-453.

Hu, L., \& Bentler, P. M. (1999). Cutoff criteria for fit indexes in covariance structure analysis: Conventional criteria versus new alternatives. Structural Equation Modeling, 6, 1-55.

Ireland, R. D., Hitt, M. A., \& Sirmon, D. G. (2003). A Model of Strategic Entrepreneurship: The Construct and its Dimensions. Journal of Management, 29(6), 963-89.

Ireland, R. D., Webb, J. W., \& Coombs, J. E. (2005). Theory and methodology in entrepreneurship research. In D. Ketchen and D. D. Bergh (Eds.), Research methodology in strategy and management, 2, 1-32.

Jaworski, B. J., \& Kohli, A. K. (1993). Market orientation: antecedents and consequences. Journal of Marketing, 57(3), 53-70.

Joreskog, K. G., \& Sorbom, D. (1984). LISREL VI users guide (3rd ed.). Moorsville, IN: Scientific Software.

Juntunen, M., Saraniemi, S., Halttu, M., \& Tähtinen, J. (2010). Corporate brand building in different stages of small business growth. Journal of Brand Management, 18(2), 115-133.

Kandampully, J., \& Suhartanto, D. (2000). Customer loyalty in the hotel industry: The role of customer satisfaction and image. International Journal of Contemporary Hospitality Management, 12(6), 346-351.

Keller, K. L. (2008). Strategic brand management (12ed). Upper Seddle River. NJ. Pearson/ Prentice-Hall.

Khasawneh, S. (2010). Human capital planning in higher education institutions A strategic human resource development initiative in Jordan. International Journal of Educational Management, 25(6), 534-544.

Kianto, A. (2009). Development and validation of a survey instrument for measuring organisational renewal capability, Int. J. Technology Management, 42(1/2), 69-88.

Kline, R. B. (1998). Principles and Practice of Structural Equation Modeling. New York, Guilford Press. 
Kline, R. B. (2005). Principles and practice of structural equation modeling ( $2^{\text {nd }}$ ed.). New York: The Guilford Press.

Koo, D. M. (2003). Inter-relationships among store images, store satisfaction, and store loyalty among Korea discount retail patrons. Asia Pacific Journal of Marketing and Logistics, 15(4), 42-71.

Lechner, C. and Gudmundsson, S. V., (2012) "Superior value creation in sports teams: Resources and managerial experience.”,M@n@gement3/2012 (Vol.15),p.284-312.

Lemieux-Charles, L., \& McGuire, W. L. (2006). What we know about health care team effectiveness: A review of the literature. Medical Care Research and Review, 63, 263-300.

Lewin, R., \& Regine, B. (1999). On the Edge in the World of Business. In Lewin, R. Complexity: Life at the Edge of Chaos. The University of Chicago Press, 197-211.

Lichtenstein B., \& Brush, C. (2001). How do "resource bundles" develop and change in new ventures? A dynamic model and longitudinal exploration. Entrepreneurship: Theory and Practice, 25(3), 37-59.

Lockett, A., Thompson, S., \& Morgenstern, U. (2009). The development of the resource-based view of the firm: a critical appraisal. International Journal of Management Reviews, 11(1), 9-28.

Love, E., \& Kraatz, M. (2005). How do firms' actions influence corporate reputation? The case of downsizing at large U.S. firms. Academy of Management Best Paper Proceedings.

Mauws, M.K., Mason, D. S. \& Foster, W. M. (2003). Thinking strategically about professional sports. European Sport Management Quarterly, 3 (3), 145-164.

McDonald, R. P., \& Ho, M. H. R. (2002). Principles and practice in reporting statistical equation analyses. Psychological Methods, 7(1), 64-82.

Miller, D. (1996). Configurations revisited. Strategic Management Journal, 17(7), 505-512.

Miller, D., \& Shamsie, J. (1996). The resource-based view of the firm in two environments: The Hollywood firm studios from 1936 to 1965. Academy of Management Journal, 39(3), 519-543.

Mnzava, B, (2013) "Do intangible investments matter? Evidence from soccer corporations", Sport, Business and Management: An International Journal, Vol. 3 Iss: 2, pp.158-168

Murthy, V. \& Mouritsen, J. (2011). The performance of intellectual capital mobilizing relationships between intellectual and financial capital in a bank. Accounting, Auditing and Accountability Journal, 24(5), 622-646.

Nelson, R. R. (1991).Why do firms differ, and how does it matter? Strategic Management Journal, $12,61-74$.

Nelson, R., \& S. Winter (1982). An Evolutionary Theory of Economic Change. Belknap Press of Harvard University Press: Cambridge MA.

Newbert, S. L. (2007). Empirical research on the resource-based view of the firm: an assessment and suggestions for future research. Strategic Management Journal, 28, 121-146.

Pan, S. L., Tan, B. C. C., Huang, J., \& Poulsen, B. (2007). The development paths of non-strategic capabilities. European Management Journal, 25(5), 344-358.

Park, C. W., Jaworski, B. J., \& Maclnnis, D. J. (1986). Strategic brand concept-image management. Journal of Marketing, 50(4), 135-145. 
Phillips, L. W., Chang, D. R., \& Buzzell, R. D. (1983). Product quality, cost position, and business performance: a test of some key hypotheses. Journal of Marketing, 37, 26-43.

Podsakoff, P. M., \& Organ, D.W. (1986). Self-Reports in Organizational Research: Problems and Prospects. Journal of Management, 12(4), 531-44.

Poppo, L., \& Weigelt, K. (2000). A test of the resource-based model using baseball free agents. Journal of Economics and Management Strategy, 9, 585-614.

Porter ME. (1985). Competitive Advantage. The Free Press: New York.

Prahalad, C. K., \& Hamel G. (1990). The core competence of the corporation. Harvard Business Review, 68(3),79-91.

Prajogo, D., \& McDermott, P. (2011). Examining Competitive Priorities/Advantage in Service Organizations (using Importance Performance Analysis). Managing Service Quality, 21(5), 465-483.

Price, J. (1997). Handbook of organizational measurement. International Journal of Manpower, 18 $(4 / 5 / 6), 305-558$.

Ratten, V. (2011). Sport-based entrepreneurship. Towards a new theory of entrepreneurship and sport management. International Entrepreneurship and Management Journal, 7 (1), 57-69.

Rindova V. P., Williamson I. O., Petkova, A. P., and Server, J. M. (2005). Being good or being known: An empirical examination of the dimensions, antecedents, and consequences of organizational reputation. Academy of Management Journal, 48, 1033-1049.

Rivkin, J. (2000). Imitation of complex strategies. Management Science, 46, 824-844.

Roberts P. W., Dowling, G. R. (2002). Corporate reputation and sustained superior financial performance. Strategic Management Journal, 23(12), 1077-1093.

Rowley, T., \& Berman, S. L. (2000). A brand new brand of corporate social performance. Business and Society Review, 39(4), 397-418.

Salkind, N. J. (2012). Exploring Research $8^{\text {th }}$ Edition. Published by Pearson, New York, NY, USA

Schultheiss, O., \& Brunstein, J. (2005). An implicit motive perspective on competence, in Elliot, A. and Dweck, C. (Eds), Handbook of Competence and Motivation, The Guilford Press, New York, NY, 31-51.

Schultz, D. E. (2005). The loyalty paradox. Marketing Management, 14(5), 10-11.

Shortell, S. M., Marsteller, J. A., Lin, M, Pearson, M. L., Wu, S.Y., Mendel P., Cretin S., \& Rosen, M. (2004). The role of perceived team effectiveness in improving chronic illness care. Medical Care, 42, 1040-48.

Simon, A. (2010). Resources, dynamic capabilities and Australian business success. Journal of Global Business and Technology, 6(2), 12-31.

Sirmon, D. G. Hitt, M. A., \& Ireland, R. D. (2007). Managing Firm Resources in Dynamic Environments to Create Value: Looking inside the Black Box. Academy of Management Review, 32(1), 273-292.

Smart, D. L., \& Wolfe, R. A. (2000). Examining sustainable competitive advantage in intercollegiate athletics: A resource-based view. Journal of Sport Management, 14, 133-153. 
Smart, D. L., \& Wolfe, R. A. (2000). Examining sustainable competitive advantage in intercollegiate athletics: a resource-based view. Journal of Sport Management, 14(2), 133-153.

Steiger, J. H. (1990). Structural model evaluation and modification: an interval estimation approach. Multivariate Behavioural Research, 25, 173-180.

Tabachnick, B. G., \& Fidell, L. S. (2007). Using multivariate statistics, $5^{\text {th }}$ edn, Pearson/Allyn and Bacon, Boston.

Temkin-Greener, H., Gross, D., Kunitz, S. J. \& Mukamel, D. (2004). Measuring interdisciplinary team performance in a long term care setting. Medical Care, 42, 472-481.

Uddin, M. B., Hassan, M. D., \& Tarique, K. M. (2008). Three dimensional aspects of corporate social responsibility. Daffodil International University Journal of Business and Economics, 3(1), 199-212.

Warnier, V., Weppe, X., \& Lecocq, X. (2013). Extending Resource-Based Theory: Considering Strategic, Ordinary and Junk Resources. Management Decision, 51(7), 1359-1379.

Weber, M. (2008). The business case for corporate social responsibility: A company level measurement approach for CSR. European Management Journal, 26(4), 247-261.

Wicker, P. and Breuer, C. (2011). Scarcity of resources in German non-profit sport clubs. Sport Management Review, Volume 14, Issue 2, pp. 188-201.

Winter, S.G. (1987). Knowledge and competence as strategic assets. D. J. Teece. ed. The Competitive Challenge: Strategies for Industrial Innovation and Renewal, Ballinger, Cambridge, MA, 159-184.

Wu, Lei-Yu. (2006). Resources, dynamic capabilities and performance in a dynamic environment: Perceptions in Taiwanese IT enterprises. Information and Management, 43(4), 447-454.

Zou, H., \& Chen, X. (2008). Resources, Capabilities and New Venture Growth Choice. Chinese Economic Association Conference, "China's Three Decades of Economic Reform (1978-2008)". Conference paper, 1-29. 